\title{
Smartphones-Based Assistive Technology: Accessibility Features and Apps for People with Visual Impairment, and Its Usage, Challenges, and Usability Testing [Corrigendum]
}

\author{
Senjam SS, Manna S, Bascaran C. Clin Optom (Auckl). The authors apologize for this error. \\ 2021;13:311-322.
}

Page 319, Conclusion, line three, the text "inaccessible" should read "accessible".

\section{Publish your work in this journal}

Clinical Optometry is an international, peer-reviewed, open access journal publishing original research, basic science, clinical and epidemiological studies, reviews and evaluations on clinical optometry. All aspects of patient care are addressed within the journal as well as the practice of optometry including economic and business analyses. Basic and clinical research papers are published that cover all aspects of optics, refraction and its application to the theory and practice of optometry. The manuscript management system is completely online and includes a very quick and fair peer-review system, which is all easy to use. Visit http://www.dovepress.com/ testimonials.php to read real quotes from published authors. 